() Т. Г. Осипова, канд. техн. наук, доцент,

М. В. Пшенична, ст. викладач, Ю. В. Пшеничний, засл. художник України, доцент, КПІ ім. Ігоря Сікорського

\title{
ОСОБЛИВОСТІ ДИЗАЙНУ ДИТЯЧИХ КНИЖОК З ЕЛЕМЕНТАМИ «РОР-UP»
}

За допомогою системного аналізу розроблено структурну модель “дитяча книжка з елементами рор-uр", та визначено, що її складова - підсистема «засоби візуальної організації

форми" є найскладнішою та має найбільше елементів, тобто є чіткою системою візуалізації, направленою на формування дизайн-форми книги і технологію її виготовлення,

а також формує вимоги до властивостей матеріалів

та дозволяє досить чітко визначити коло факторів, пов'язаних 3 проектуванням дитячих книжок з елементами «рор-uр», що має важливе методологічне та практичне значення.

Ключові слова: дизайн книжок; дизайн-форма; ігрові елементи; елементи «рор-ир»; ілюстрування; системний аналіз книг.

\section{Постановка проблеми}

Дитячі книжки з використанням елементів «рор-ир» пройшли довгий шлях розвитку від найпростішого руху окремих елементів до абстрактних і складних конструкцій, які зробили їх частиною дизайнерського мистецтва.

Дизайном таких книг у різний час займалися: Ron van der Meer, конструктор і видавець, який запропонував новий формат видань так звану книжку-контейнер, що складалася з 600 елементів, серед яких були: панорамні та рухливі елементи, відлітні полотнища, лоток для відеокасети; Роберт Sabuda, який досяг виразності інтерактивних ілюстрацій за рахунок надзвичайно складних висічених конструкцій з білого або однокольорового паперу; David
A. Carter, що випустив серію видань 3 використанням розкривних геометричних фігур різних за формою та ін. [1-6].

Зараз, дитяча книга (взагалі, і в тому числі з використанням елементів «рор-ир»), вивчається з точки зору якості змісту авторського тексту, ілюстративного ряду та їх впливу на дитяче сприйняття, естетичне та моральне виховання дитини [7, 8]. Роботи, у яких дизайн дитячих книг з використанням елементів «рор-ир» розглядається як синтез змісту ілюстрацій, особливостей створення дизайнформи та технології виготовлення, зустрічаються рідко. Тому застосування системного підходу для дослідження особливостей дизайну дитячих книжок з елементами

(๔) $2018 \mathrm{p}$. 
«рор-uр» для визначення шляхів оптимізації процесу їх проектування $€$ актуальним.

\section{Мета роботи}

3'ясувати основи конструктивної організації дизайн-форми дитячих книжок 3 елементами «рор-uр», виявити фактори, що впливають на дизайн такого типу книжок та науково обґрунтувати характер зв'язків між ними й визначити головні фактори у проектно-художньому формоутворенні.

\section{Результати проведених досліджень}

За допомогою методів аналізу та синтезу опрацьовано певний сегмент ринку книжок «рор-ир», які видано в Україні та за її межами, з метою створення їх класифікації з урахуванням особливості конструктивного оформлення.

Якість дизайну книжок «рор-uр», залежить від художньо-образного оформлення, конструкції дизайн-форми і властивостей матеріалів, що забезпечують надійність в експлуатації.

Тому для виявлення основних завдань, які необхідно вирішити для підвищення якості проектування книжок з елементами «рор-uр», було застосовано системний аналіз [9, 10], який дозволив встановити структурні зв'язки між змінними і постійними елементами системи (дитяча книга з елементами рор-uр») та визначити шляхи оптимізації процесу їх проектування.

Головним фактором, який впливає на якість та надійність конструкції дизайн-форми книжок з елементами «рор-uр», є властивості паперу [11]. Тому під час вибору паперу та картону, для розробки загальної творчої концепції книжок (Д. Родарі «Чарівна Палиця», Г. Андерсен «Дюймовочка», «Коза-дереза»), враховували і опір вигину, і міцність на злам.

Для цього було відібрано шість видів паперу: Magna Satin (200 г/M²) 3 ламінацією плівкою товщиною 100 мкм; Daewoo Power

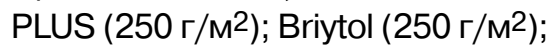
Graphiart Duo (220 г/M²); Graphiart Duo (235 г/м²); Graphiart Duo (255 г/м²), які досліджувалися на опір вигину, міцність на злам та на розрив.

Міцність на розрив визначалася на розривній машині РМ-50 за певної швидкості переміщення затиску до розриву зразка (ДСТУ 2334-94 (ГОСТ ISO 1924.1-96) і потім розраховували за формулою:

$$
L=\frac{I_{0} \cdot F}{m} \cdot 100 \text {, }
$$

де $\mathrm{I}_{0}$ - довжина смужки між затискачами, м; F - руйнівне зусилля (середнє арифметичне п'яти-десяти вимірів), $\mathrm{H}$; $\mathrm{m}$ - середня маса смужки, г.

Для визначення опору вигину відібрані зразки паперу розрізали на смужки розміром 38×52 мм, зразок паперу, закріплений одним кінцем на приладі марки SE 01.8, загинали на кут $15^{\circ}$, фіксували результати і розраховували силу вигину F, за формулою:

$$
F=\frac{R}{L},
$$

де R - згинальний момент, мН·см; $\mathrm{L}$ - довжина зразка.

Міцність на злам при багаторазових перегинах визначали за кількістю подвійних перегинів до зламу на приладі UGT6014 - 
для цього зразки розміром 15×100 мм встановлювали у затискачах і перегинали у дві сторони до зламу зразка ГОСТ 1352552-80. Товщину зразків визначали товщиноміром UHA-FT3.

Головним етапом у проектуванні дитячих книжок «рор-ир» $€$ їхнє класифікування. Результат аналітичних досліджень книжок «рор-uр» з точки зору застосування рухомих елементів і базових конструкцій став підставою для розробки такої класіфікації.

За своєю конструкцією книжки «рор-ир» можуть бути зроблені з одного аркуша або з декількох фрагментів, скріплених між собою; можуть мати різний кут розкриття базових сторінок: $0^{\circ} ; 90^{\circ} ; 180^{\circ}$; $360^{\circ}$; можуть містити кінематичні конструкції 3 інтерактивними ілюстраціями, які розгортаються без додаткової допомоги, та ті, які розгортаються власноруч, або за допомогою різноманітних важелів, стрічок, шнурків, язичків та інших елементів.

Як складові елементи використовуються: рухомі конструкції, що знаходяться на площині: обертові кола або диски, які прикріплені до сторінки у центральній точці; відкидні клапани, таблиці, які витягуються й розкладаються; конструкції, що піднімаються: сцена, V-подібна складка, коробка або циліндр, ковзні площини.

Висновки про використання в книжках типу «рор-ир» конструкцій та складових елементів наведено в таблицях 1, 2.

Таблиця 1

Класифікація базових конструкцій книжок «рор-ир»

\begin{tabular}{|c|c|c|c|}
\hline $\begin{array}{c}\text { Схематичне } \\
\text { зображення } \\
\text { конструкції }\end{array}$ & Опис конструкції & $\begin{array}{c}\text { Схематичне } \\
\text { зображення } \\
\text { конструкції }\end{array}$ & Опис конструкції \\
\hline & $\begin{array}{l}\text { Ефект «рор-ир» дося- } \\
\text { гається при розкритті } \\
\text { книги на 90. } \\
\text { Конструктивний еле- } \\
\text { мент у вигляді однієї } \\
\text { полиці або декількох, } \\
\text { каскадного типу, утво- } \\
\text { рюється за допомогою } \\
\text { висікання і паралельних } \\
\text { до корінця згинів. } \\
\text { Елемент може бути як } \\
\text { додатковою вставкою, } \\
\text { так і вирізатися безпо- } \\
\text { середньо з основи. }\end{array}$ & & $\begin{array}{l}\text { Ефект «рор-ир» до- } \\
\text { сягається при роз- } \\
\text { критті книги на 180. } \\
\text { Конструктивний еле- } \\
\text { мент розташовано } \\
\text { вертикально віднос- } \\
\text { но основи. } \\
\text { Елемент створюється } \\
\text { за допомогою додат- } \\
\text { кової вставки. }\end{array}$ \\
\hline & $\begin{array}{l}\text { Ефект рор-ир дося- } \\
\text { гається при розкритті } \\
\text { книги на } 360^{\circ} . \text { Сторінки } \\
\text { утворюють конструк- } \\
\text { тивний елемент з ба- } \\
\text { гатьма перегинами. } \\
\text { Елемент створюється } \\
\text { допомогою додаткової } \\
\text { вставки. }\end{array}$ & & $\begin{array}{l}\text { Конструкція не вима- } \\
\text { гає розкриття для от- } \\
\text { римання візуального } \\
\text { ефекту. Елементи ут- } \\
\text { ворюють додаткову } \\
\text { площину над осно- } \\
\text { вою, та створюються } \\
\text { як за допомогою до- } \\
\text { даткової вставки так і } \\
\text { за рахунок висічки без- } \\
\text { посередньо з основи. }\end{array}$ \\
\hline
\end{tabular}




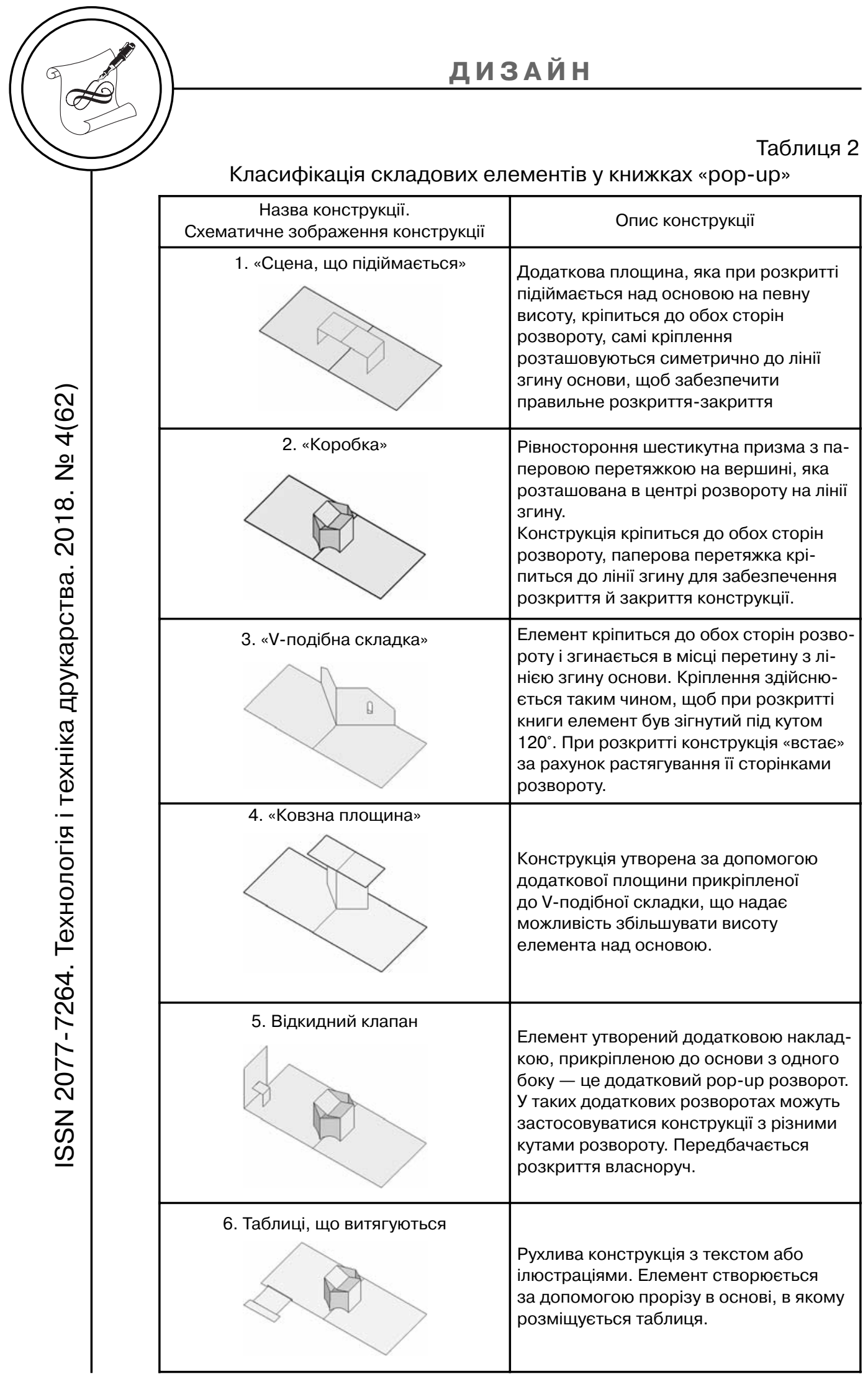




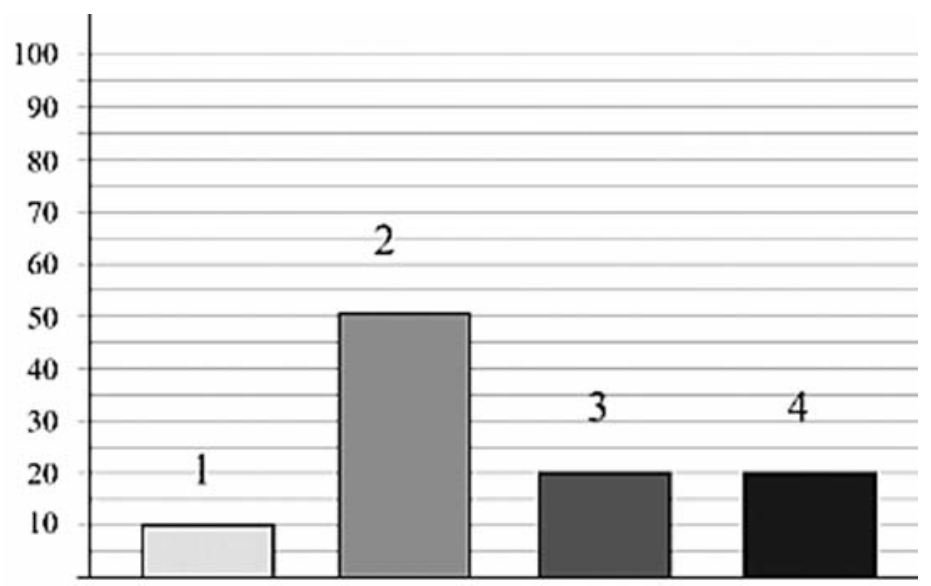

Рис. 1. Діаграма частоти використання базових конструкцій:

$$
1-0^{\circ} ; 2-90^{\circ} ; 3-180^{\circ} ; 4-360^{\circ}
$$

На рис. 1 наведено діаграму частоти використання базових конструкцій. Вона демонструє, що переважно використовуються конструкції, в яких ефект «рор-ир» досягається при розкритті книги на $-90^{\circ}$ (відповідає найбільш поширеним в Україні книжкампанорамкам) та $-180^{\circ}$, лідером у випуску котрих на сьогодні $€$ Китай.

3 діаграми частоти використання складових елементів книжок «рор-ир» (рис. 2), видно, що найчастіше використовуються такі конструкції: «сцена, що піднімається», «коробка», «V-подібна складка», «змінна площина», які створюють максимальний візуальний ефект.

Наведені вище приклади дизайну дитячих книжок «рор-ир» демонструють здатність книжкової форми трансформуватися залежно від включення в неї тих чи інших ігрових елементів, а також забезпечують навчальний і виховний вплив на дітей.

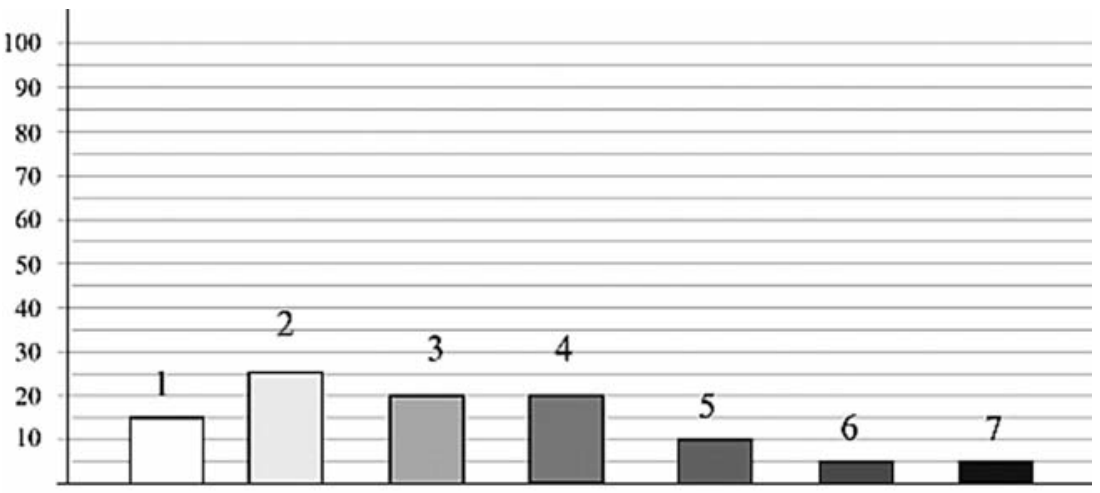

Рис. 2. Діаграма частоти використання складових елементів книжок рор-ир 
Неможливо створити оптимальну дизайн-форму і художнє оформлення без комплексного підходу до проектування. За допомогою системного підходу впорядкуємо своє уявлення про дитячу книжка типу «рор-ир» як систему, та відтворімо її у структурній моделі.

Під метою системи «дитяча книжка типу «рор-ир» розуміємо забезпечення процесу передавання знань про реальне середовище, яке виражено в словесних, художніх та наукових образах і поняттях, а також спрямоване на розвиток, виховання, навчання та соціалізацію дитини.

Спершу уявімо систему «дитяча книжка з елементами рор-uр», у вигляді моделі типу «чорна скринька». Як вхідні елементи моделі використаємо зміст авторського літературного тексту, художньографічні засоби дизайн-проектування, конструкцію книжкової форми, а як вихідні - функції дитячої літератури: розважальна (отримання задоволення від читання книг); освітня (пізнання навколишнього світу); риторична (розвиток мови); комунікативна (передача інформації або спонукання до дії); естетична (виховання естетичного смаку, почуття прекрасного). Визначені елементи «входу» та «виходу» системи дозволяють 3'ясувати, які саме компоненти повинні використовуватися, і, яким чином вони співвідносяться з метою, проте, мало що говорять про внутрішній устрій системи. Тому, для більш детального аналізу системи «дитяча книжка з елементами рор-uр», розіб'ємо її на декілька підсистем: візуалізації та функціонального використання. Метою першої $€$ створення предмету мистецтва, а другої - утилітарне використання.

Враховуючи, що виходи відповідають конкретизації мети, фіксуємо як вихід для підсистеми «дитяча книжка з елементами рор-up» $\rightarrow$ мистецька складова» такі показники: візуальна організація форми, гармонія візуальної форми, забезпечення емоційнопсихологічного балансу, а як вхід композиційні засоби, художньообразне рішення, концептуальне вирішення дизайн-форми; та для підсистеми «дитяча книжка з елементами «рор-uр»-функціональна (утилітарна) складова» як вихід - ергономічний баланс, створення функціонального комфорту для дитини, надійність конструкції, а як вхід - конструкція книжкової форми, ергономічні, функціональні та технологічні показники.

Кожна з цих підсистем має ієрархічний ряд власних взаємозалежних структурних елементів, що дозволяє враховувати багатоаспектність інформації та ступінь іï взаємодії з іншими елементами та їхніми угрупованнями під час вирішення конкретних задач щодо проектування дитячих книжок з елементами «рор-up», i, нарешті, на кінцевому етапі об'єднати їх у модель структури системи, що надає можливість визначити характер поведінки системи, тенденції та перспективи проектування.

До складу моделі структури системи «дитяча книжка з елементами «рор-uр» - (1-й рівень), входять дві системи (2-й рівень) «дитяча книжка 3 елементами рор-uр як витвір мистецтва» та «дитяча книжка 3 елементами рор-up як утилітарна функція», 
які в свою чергу мають дві підсистеми (3-й рівень): засоби візуальної організації форми та забезпечення емоційно-психологічного стану; принципи створення функціонального комфорту та засоби створення дизайн-форми; котрі мають такі елементи (4-й рівень): композиційні прийоми, форма, формалізація, стильова єдність, цілісність, пропорційність; функціональність, ергономічність, технологічність, конструктивність. Елементи «композиційні прийоми» та «форма», «технологічність» та «конструктивність» в свою чергу поділяються на піделементи (5-й рівень): симетрія, масштабність, ритм, контраст; лінія, матеріали тощо.

Підсистема «засоби візуальної організації форми» $€$ найскладнішою і багатоелементною та $€$ чіткою системою візуалізації, направленою на формування дизайн-форми книги, технологію виготовлення та формує вимоги щодо властивостей матеріалів і дозволяє досить чітко визначити коло факторів, які впливають на проектування дитячих книжок з елементами «рор-uр», що має важливе методологічне та практичне значення.

Отже, у проектуванні дизайнформи важливу роль відіграють властивості матеріалів. Тому для вибору паперу, який може забезпечити надійність конструкції дизайн-форми були досліджені механічні властивості відібраних зразків паперу, дані випробувань наведено на пентограмі (рис. 4).

Встановлено, що найкращі показники стійкості на злам та опору розриву спостерігаються

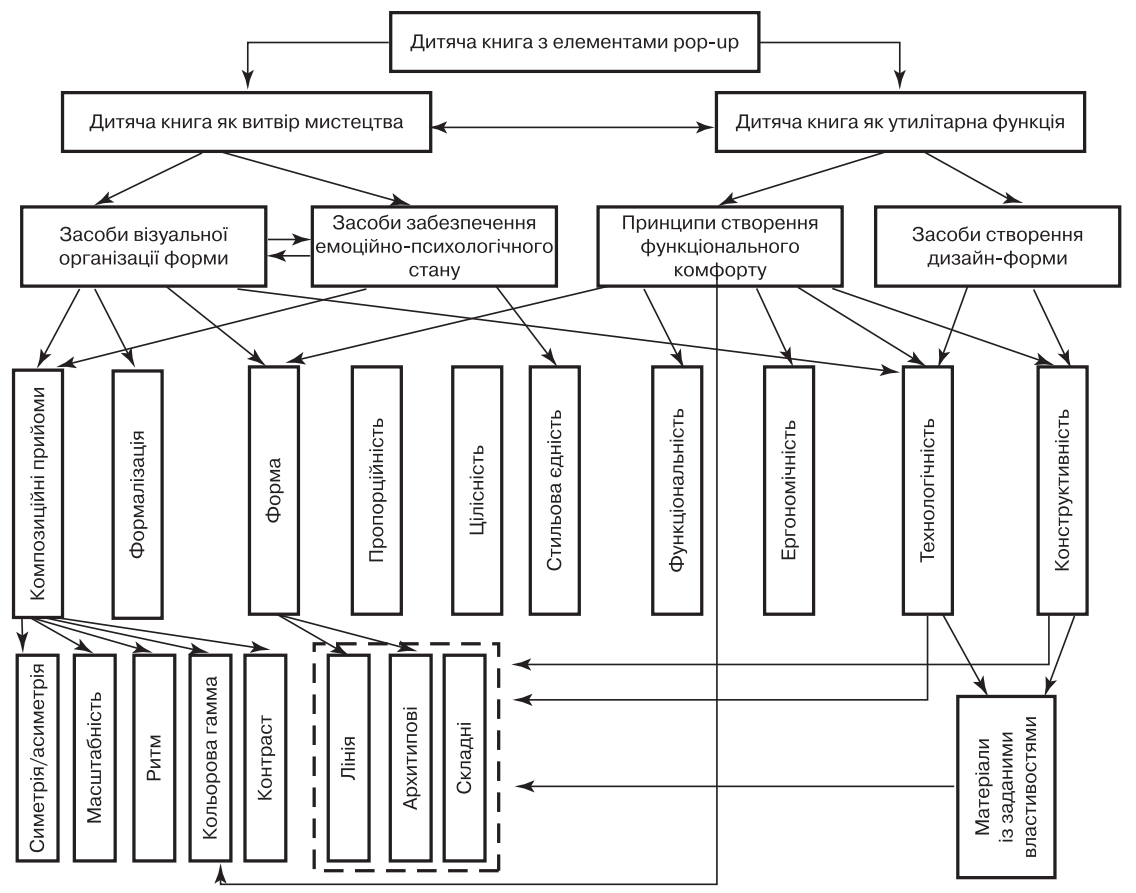

Рис. 3. Графічна модель структури системи «дитяча книжка з елементами «рор-ир» 
у зразка № 1, що обумовлено не властивостями паперу, а наявністю припресованої плівки; на другому місці за цими показниками $\epsilon$ картон під № 6, який має в своєму складі рослинні волокна. На третьому місці - зразок під № 5, який має досить стабільні результати. Проте, багатошаровий характер структури зразка № 1, якому відповідає папір Magna Satin $з$ припресованою плівкою, здатний забезпечити механічну міцність і необхідні деформаційні властивості під час виготовлення дизайн-форм книжок «рор-ир».

Результати проведених досліджень використано в проектуванні різних за конструкцією книжок у рамках виконання курсових, бакалаврських та магістерських робіт на кафедрі графіки, серед яких слід зазначити дизайн книжок: Д. Родарі «Чарівна Палиця» (Кулаківська А., керівник Осипова Т. Г.), Г. Х. Андерсен «Дюймовочка» (Речинська М., керівник Пшенична
М. В.), «Коза-дереза» (Руснак О., керівник Пшеничний Ю. В.), приклади розворотів наведено на рис. 5.

Для виготовлення конструктивних елементів «рор-ир» до книжок Д. Родарі «Чарівна Палиця» та Г. Х. Андерсен «Дюймовочка» обрано базові конструкції дизайнформ, в яких ефект «рор-ир» досягається при розкритті книги на $180^{\circ}$, а як складові елементи застосовано: сцену, що підіймається, коробку, V-подібну складку, ковзну площину та відкидний клапан. Дизайн книги «Коза-дереза» базується на ефекті «рор-ир» при розкритті книги на 90, і як конструктивні застосовано елементи у вигляді однієї або декількох полиць, каскадного типу, які утворюються за рахунок висікання безпосередньо з основи і паралельних до корінця згинів. Задля забезпечення надійності конструкцій у цих книжках вибрано матеріал Magna Satin + ламінація.

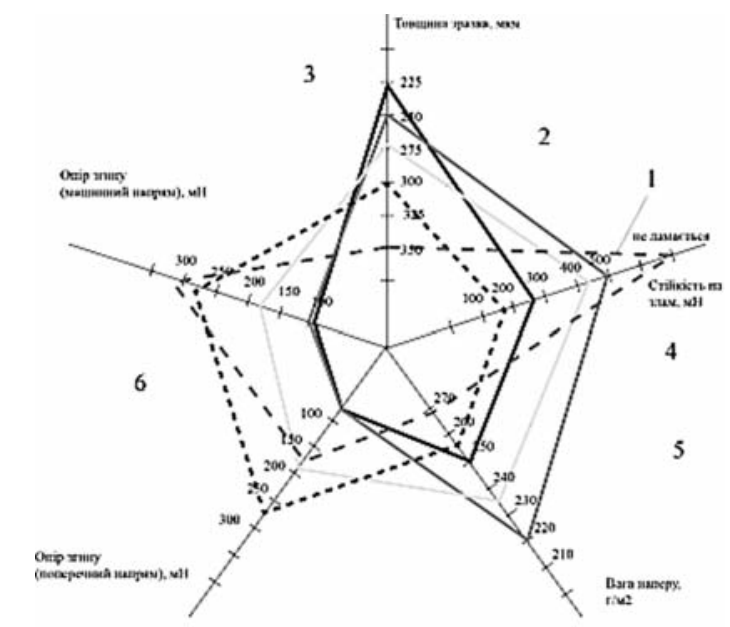

Рис. 4. Пентограма міцнісних властивостей паперу, де: 1 - Magna Satin + ламінація; 2 - Daewoo Power PLUS; 3 - Briytol; 4 - Graphiart Duo; 5 - Graphiart Duo; 6 - Graphiart Duo 

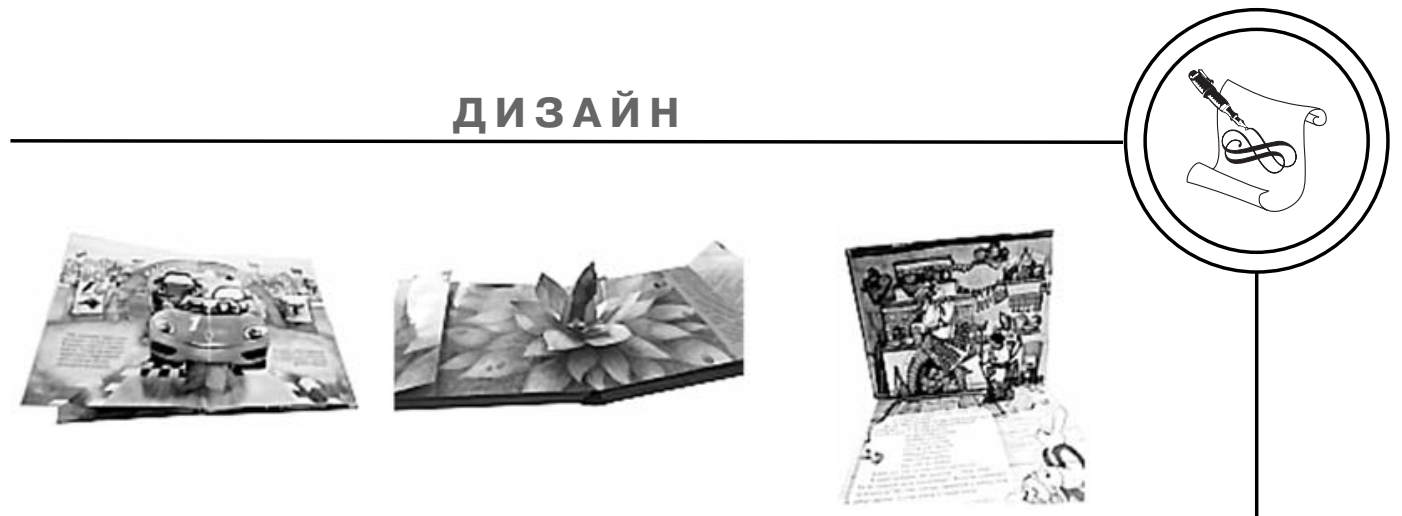

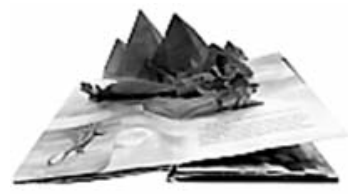

a

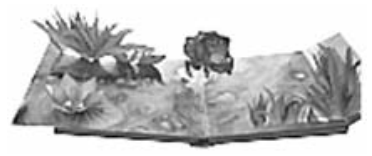

б

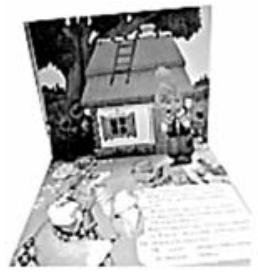

B

Рис. 5. Приклади розворотів книжок: а - Д. Родарі «Чарівна Палиця» (Кулаківська А., керівник Осипова Т. Г.), б - Г. Х. Андерсен «Дюймовочка» (Речинська М., керівник Пшенична М.В.), а — «Коза-дереза» (Руснак О., керівник Пшеничний Ю. В.)

Запропонований дизайн висвітлює сучасні тенденції формоутворення дитячих «рор-ир» книжок, забезпечує функціональну та композиційну єдність книжкової конструкції, що сприяє підвищенню естетичних якостей дитячої книги.

\section{Висновки}

1. На основі узагальнення вітчизняного та зарубіжного досвіду в галузі проектування дитячих книжок з елементами «рор-uр» визначено та систематизовано конструктивні особливості загальної дизайн-форми та форми окремих елементів та запропоновано їх класифікацію.

2. На основі системного аналізу розроблено структурну мо- дель «дитяча книжка з елементами рор-uр», що дозволило теоретично обґрунтувати дитячу книжку з елементами «рор-ир» як науковий об'єкт дослідження, виявити фактори, що впливають на дизайн такого типу книжок, та встановити характер зв'язків між ними й визначити головні у проектно-художньому формоутворенні.

3. Встановлено, що найкращі показники стійкості на злам та опору розриву належать паперу Magna Satin $з$ припресованою плівкою, який здатний забезпечити механічну міцність і необхідні деформаційні властивості при виготовленні дизайн-форм книжок «рор-ир».

\section{Список використаної літератури}

1. Abrahamson, Richard F. Movable books - a new golden age // Language arts. 1982. April. v. 5. p. 342.

2. Dawson, Michael. Checklist of books written, edited and/or published by S. Louis Giraud // Antiquarian book monthly review. 1992. June. 19:266-271. 
3. Dawson, Michael. Children's pop-ups, movables and novelty books: A short history for collectors, part II // Movable stationery. 1995. December. 3:6. pp. 1, 8-10.

4. Krahe, Hildegard E. The importance of being Ernest Nister // Phaedrus. 1988. pp. 73-90.

5. Seymour, Peter. The resurrection of the pop-up book // Publishers weekly. 1981. February 27. 219:97-99.

6. Taylor, Sally A. Intervisual Communications: Popping up all over // Publishers weekly. 1991. July 26. 238:217-218.

7. Попова Д. М. Проектные задачи в дизайне детской книжки-игрушки / Д. М. Попова // Архитектон: известия вузов. 2012. № 3(39). [Электронный ресурс]. Режим доступа: http://archvuz.ru/2012_3/16. ISSN 1990-4126.

8. Арнхейм Р. Искусство и визуальное восприятие / Рудольф Арнхейм; пер. с англ. В. Самохина. Москва: Архитектура-С, 2007. 392 с.

9. Вайсман Л. М. Структура бумаги и методы ее контроля / Л. М. Вайсман. Москва: Лесная промышленность. 1973. 152 с.

10. Эддоус М. Методы принятия решений / М. Эддоус, Р. Стэнсфилд; пер. с англ. И. И. Елисеевой. Москва: Аудит, ЮНИТИ, 1997. 590 с.

11. Саати Т. Принятие решений. Метод анализа иерархий / Т. Саати; пер. с англ. Р. Г. Вачнадзе. Москва: Радио и связь, 1993. 278 с.

\section{References}

1. Abrahamson, Richard F. (1982). Movable books - a new golden age // Journal of Language arts, 5, 342 [in English].

2. Dawson, Michael. (1992). Checklist of books written, edited and/or published by S. Louis Giraud. Journal of Antiquarian book monthly review, 19:266-271 [in English].

3. Dawson, Michael. (1995). Children's pop-ups, movables and novelty books: A short history for collectors, part II. Journal of Movable stationery, 3:6, 1, 8-10 [in English].

4. Krahe, Hildegard E. (1988). The importance of being Ernest Nister. Journal of Phaedrus, 73-90 [in English].

5. Seymour, Peter. (1981). The resurrection of the pop-up book. Journal of Publishers weekly, 219:97-99 [in English].

6. Taylor, Sally A. (1991). Intervisual Communications: Popping up all over. Journal of Publishers weekly, 238:217-218 [in English].

7. Popova, D. M. (2012). Proektnye zadachi v dizayne detskoy knizhki-igrushki. Journal of Arkhitekton: izvestiya vuzov, 3(39). Retrieved from http:// archvuz.ru/2012_3/16. ISSN 1990-4126 [in Russian].

8. Arnkheym, R. (2007). Iskusstvo i vizual'noe vospriyatie. Moscow: Arkhitektura-S, 392 p. [in Russian].

9. Vaysman, L. M. (1973). Struktura bumagi i metody ee kontrolya. Moscow: Lesnaya promyshlennost', 152 p. [in Russian].

10. Eddous, M. \& Stensfild, R. (1997). Metody prinyatiya resheniy. Moscow: Audit, YuNITI, 590 p. [in Russian].

11. Saati, T. (1993). Prinyatie resheniy. Metod analiza ierarkhiy. Moscow: Radio i svyaz', 278 p. [in Russian]. 
Детскую книгу с элементами «рор-ир» рассмотрено как синтез искусств, коммуникаций и функциональных свойств. Проведен углубленный анализ использования дизайн-форм и разработана их классификация.

Построены диаграммы частоты использования составных элементов книг «рор-ир» и установлено, что для создания максимального визуального эффекта чаще всего используются следующие конструкции: «поднимающаяся сцена», «коробка», «V-образная складка», «скользящая плоскость».

Ключевые слова: дизайн книг; дизайн-форма; игровые элементы; элементы «рор-uр"; иллюстрирование; системный анализ книг.

Children's pop-up books are considered to be the synthesis of arts, communications and functional properties. The deep analysis of design-form use has been conducted and their classification has been worked out. The diagrams of component elements frequency use in pop-up books have been built and it has been established that maximal visual effect is acquired by dint of the most widely used constructions of the 'rising stage', 'box', 'V-shape fold' and 'sliding plane'.

Keywords: book design; design-form; playing elements; elements of 'pop-up'; illustration; books' systems analysis.

Рецензент - В. Є. Перевальський, доцент, народний художник України, академік НАМ України 